\title{
Nonpayment Risk Multipliers: Incentives or Windfalls?
}

The Civil Rights Attorney's Fees Award Act of 1976 authorizes courts to award reasonable attorney's fees to prevailing parties in specified civil rights litigation. ${ }^{1}$ While the legislative history of the Act provides some indication of how to define "reasonable fees," Congress essentially deferred to the courts' judgment of reasonableness, ${ }^{2}$ giving the courts a quasi-legislative, quasi-executive power to set the appropriate level of civil rights enforcement. ${ }^{3}$

Because the level of fee awards directly affects the number of civil rights cases litigated, fee awards have produced controversy both in and out of the courts. ${ }^{4}$ This comment examines one aspect of the controversy-whether attorney fees derived from a lawyer's

1 "In any action or proceeding to enforce a provision of sections 1981, 1982, 1983, 1985, and 1986 of the Revised Statutes, title IX of this title, title IX of Public Law 92-318 [20 U.S.C. 1681 et seq.], or title VI of the Civil Rights Act of 1964 [42 U.S.C. 2000 d et seq.], the court, in its discretion, may allow the prevailing party, other than the United States, a reasonable attorney's fee as part of the costs." 42 U.S.C. § 1988 (1982) (hereinafter Fees Act).

42 U.S.C. $\$ 1983$, in particular, provides a cause of action against governmental officials who violate a plaintiff's constitutional rights under color of state law. Throughout this comment the fees awards issues are discussed in the context of section 1983 suits because "it is the inclusion of 42 U.S.C. $\S 1983$. . . that makes the [Fees] Act an extremely broad 'generic' fee provision." M. Derfner, The Civil Rights Attorney's Fees Awards Act of 1976, in Herbert B. Newberg, ed., Public Interest Practice and Fee Awards 36 (1980). In addition to the other Civil Rights statutes, the discussion of attorneys' fees issues is applicable to many other fee shifting statutes, which courts already interpret with reference to the Fees Act's legislative history. Id. at $42 \&$ n.107.

2 S. REP. No. 1011, 94Th CoNG., 2D SESS. 6 (1976) (hereinafter S. REP. No. 1011) reprinted in 1976 U.S. Code Cong. \& Admin. News 5908, also reprinted in Subcomm. on CoNstitutional Rights of the Senate Comm. on the Judiciary, 94th Cong., 2d Sess., Civil Rights Attorney's Fees Awards Act of 1976 Source Book: Legislative History, Texts, and Other Documents 4-6, 10-12 (1976) (hereinafter Source Book); H.R. ReP. No. 1558, 94Tr CoNG., 2D SESS. 6-7 (1976) (hereinafter H. REP. No. 1558), reprinted in Source Book 214-17.

3 See B. Fein, Citizen Suit Attorney Fee Shifting Awards: A Critical Examination of Government-"Subsidized" Litigation, 47 LAw \& CoNTEMP. ProBs. 211, 224-29 (Winter 1984) (criticizing delegation of policy-making authority by legislative and executive branches when it is accomplished by leaving crucial statutory terms undefined).

4 Most recently the debate has centered on proposed S. 1580 and its companion, H.R. 3181 , which would cap hourly rates charged against government defendants at $\$ 75$ and eliminate all multipliers, see infra notes 6,7 , and 15 . For a sampling of issues and cases recently before the Supreme Court, see infra note 15. See generally R. Diamond, The Firestorm over Attorney Fee Awards, 69 A.B.A. J. 1420 (1983). 
hourly rate multiplied by hours spent should be increased to compensate attorneys for taking civil rights cases on a contingent fee basis when they must bear significant risks of losing and receiving no payment. This issue currently is before the Supreme Court. ${ }^{5}$

Until recently, fee enhancement for nonpayment risk had not been widely challenged. ${ }^{6}$ Congressional hearings on nonpayment risk multipliers have done little to clarify the issue. Proponents of the multipliers contend that if risk multipliers were eliminated, many lawyers would be forced to cease their civil rights practice; opponents chronicle cases where exorbitant fees were awarded and argue that multipliers only create windfalls for attorneys. ${ }^{7}$ The is-

s See Pennsylvania v. Delaware Valley Citizens' Council, 106 S. Ct. 3088,3100 (1986) (restoring case to docket for reargument "insofar as it raises the question whether attorney's fees chargeable to a losing defendant under the Clean Water Act and the comparable statutes may be enhanced based on risk of loss, and if so, to what extent").

- Id. See also Blum v. Stenson, 465 U.S. 886, 901 n. 17 (1984). Only one case prior to Blum suggests that enhancement for nonrecovery risk is impermissible. See Bonner v. Coughlin, 657 F.2d 931, 936 (7th Cir. 1981) ("The contingent nature of the fee is an appropriate factor to weigh in determining the overall reasonableness of the fee, but it alone does not justify the use of a multiplier."). For a general survey of the courts of appeals' reactions to Blum, see Wildman v. Lerner Stores Corp., 771 F.2d 605, 611 (1st Cir. 1985). See also The Legal Fee Equity Act, Hearings on S. 1580, S. 1794, and S. 1795 Berore the Subcomm. on the Constitution of the Senate Comm. on the Judiciary, 99th Cong., 1st Sess. (1985) (hereinafter Equity Act Hzarings II); The Legal Fees Equity Act, Hearings on S. 2802 Before the Subcomm. on the Constitution of the Senate Comm. on the Judiciary, 98th Cong., 2d Sess. (1984) (Equity Act Hearings I).

7 For the arguments of plaintiff's lawyers, see, e.g., Equity Act Hearings II at 290 (testimony of Philip G. Sunderland, civil rights lawyer in Washington, D.C.) (claiming that Equity Act's prohibition on multiplier and $\$ 75$ hourly rate cap "will terminate the ability and ... willingness of my firm to continue providing contingent representation in environmental, civil rights and similar cases involving governmental defendants"); EQUITY ACT Hearings I at 383-98 (testimony of Charles V. McTeer, civil rights lawyer practicing in Greenville, Miss.); Attorney's Fees Awards: Hearings on S. 585 Before the Subcomm. on the Constitution of the Senate Comm. on the Judiciary, 97th Cong., 2d Sess. 53-54 (1982) (testimony of Fletcher Farrington, civil rights lawyer practicing in Savannah, Ga.) ("Absent contingency or multiplier adjustments, this amendment [would] end my civil rights practice on behalf of plaintiffs.").

For the opposing views, see, e.g., Equity Act Hearings I at 41.42 (statement of Carol Dinkins, Deputy Attorney General, U.S. Dept. of Justice) (criticizing Harvard law professor Laurence $H$. Tribe's fee claim for $\$ 275$ per hour plus a 50 percent multiplier after his success in convincing the Supreme Court to strike down a Massachussetts law that permitted churches and schools to veto liquor licenses granted in their neighborhoods); NationaL Association of Attorneys General, Report to Congress: Civil Rights Attorney's Fees AwARDs ACT of 1976 32, 35 (1984) (hereinafter NAAG REPORT), reprinted in EquiTY ACT HeArings I at 241, 280-83 (noting "devastating" burden on state treasuries from excessive attorney's fee awards, quoting judges and commentators who believe "fee abuses are a serious problem," and recommending a maximum fee of $\$ 75$ per hour) (footnotes omitted); $R$. Fioretti \& J. Convery, Attorney's Fees Under the Civil Rights Act-A Time For Change, 16 J. MAR. L. REv. 261, 284-86 (1983) (arguing that change is necessary because "[C]ongress clearly did not intend the extreme financial burdens now being placed on units of local 
sues that the Fees Act left open thus remain unresolved: what level of private civil rights enforcement is desired and are risk multipliers necessary to achieve that level?

Federal courts of appeals have not been consistent in answering these questions. A majority allows fee enhancement to compensate lawyers for nonpayment risk, ${ }^{8}$ and many courts have concluded that an attorney's fee is not "reasonable" unless the lawyer is compensated for bearing the risk of nonpayment. ${ }^{9}$ After all, it is argued, what lawyer would choose contingent fee litigation at his normal billing rate over his normal guaranteed fee work? In addition, some courts have argued that the legislative history is dispositive because the Senate report on the Fees Act approved of cases that employed a "contingency enhancement."10

Some courts, however, have expressed serious doubts about nonpayment risk fee enhancement generally, and have disallowed contingency multipliers in particular. ${ }^{11}$ In part, they have responded to recent Supreme Court decisions that have encouraged out-of-court settlement of fee claims, limited the fee enhancement discretion of courts, and questioned the use of nonpayment risk multipliers. ${ }^{12}$ But these courts likewise have cited the legislative history and the Congressional floor debates to defend their view, emphasizing that Congress intended reasonable attorney's fees to be awarded only to prevailing parties. ${ }^{13}$ This intent arguably is

government").

Seven out of nine circuits that have considered the propriety of contingency multipliers since Blum have allowed them. See infra note 56 .

- See, e.g., Wildman v. Lerner Stores Corp., 771 F.2d at 613 ("To deny all consideration of [nonpayment risks] does not strike us as 'reasonable." ").

${ }^{10}$ See, e.g., Hall v. Borough of Roselle, 747 F.2d 838, 843 (3d Cir. 1984) (quoting Blum v. Stenson, 465 U.S. 886, 903 (1984) (Brennan, J., concurring)).

1 See, e.g., McKinnon v. City of Berwyn, 750 F.2d 1383, 1392-93 (7th Cir. 1984); Laffey v. Northwest Airlines, Inc., 746 F.2d 4, 26-29 (D.C. Cir. 1984) (distinguishing contingency enhancement from multipliers calculated by taking the inverse of the probability of success). To avoid confusion in terminology, this comment generally uses the term "nonpayment risk multipliers," using "contingency multipliers" only when discussing cases, some of which justify contingency multipliers with reference to factors other than nonpayment risk. See notes 88-91 and accompanying text.

12 See Evans v. Jeff D., 106 S. Ct. 1531 (1986); Marek v. Chesny, 105 S. Ct. 3012 (1985) (holding that attorney's fees are included in Rule 68 costs that shift to plaintiff when eventual judgment does not exceed settlement offer); Blum v. Stenson, 465 U.S. 886 (1984); Hensley v. Eckerhart, 461 U.S. 424 (1983) (fee award should be adjusted downward because plaintiff only "partially" succeeded).

3s McKinnon, 750 F.2d at 1392 (contingency multiplier would indirectly compensate non-prevailing parties, while fee-shifting under the statute is expressly limited to prevailing parties). See also S. REP. No. 1011 at 4 (party seeking to enforce protected rights should ordinarily recover attorney's fees "if successful"). 
frustrated by a system that awards fees inversely proportional to the probability of success. Such a system effectively, albeit indirectly, may subsidize nonprevailing cases because attorneys can bring a portfolio of non-meritorious cases expecting to win one and thereby finance the losing cases with the nonpayment risk bonus. Even absent the assumption that attorneys use the bonus to finance a portfolio of risky litigation, courts are concerned that contingency bonuses may provide windfalls to attorneys and create unintended incentives for lawyers to represent non-meritorious claims. Either of these results is in direct conflict with Congress's explicit intent. ${ }^{14}$

The debate over nonpayment risk multipliers is rooted in the competing policy goals of the Fees Act: the desire to encourage lawyers to represent indigent civil rights plaintiffs must be balanced against the dangers of providing windfalls to attorneys, encouraging frivolous claims, and generating litigation over attorney's fees. To analyze this conflict, this comment begins with an examination of the relevant case law. Part I first surveys the Supreme Court's recent efforts to achieve a more coherent interpretation of the "reasonable fees" provision of the Fees Act. It then reviews the various attempts by the courts of appeals to apply this interpretation to the issue of risk multipliers. After finding the legislative history ambiguous on the issue, Part II turns to a detailed policy analysis of nonpayment risk multipliers. The comment concludes that on balance the policy arguments weigh against the use of contingency multipliers and thus, in the absence of clear evidence of congressional intent, the Supreme Court should hold such multipliers impermissible under the Fees Act.

\section{The Contingency Multiplier Debate in the Courts}

\section{A. Attorney's Fees Issues in the Supreme Court}

Attorney fee shifting and the incentives it creates have been the subject of increasing litigation, congressional attention, and academic debate in recent years. ${ }^{13}$ More than 100 federal statutes

14 See, e.g., McKinnon, 750 F.2d at 1392-93; Laffey, 746 F.2d at 26-29; Murray v. Weinberger, 741 F.2d 1423, 1430-33 (D.C. Cir. 1984).

${ }_{15}$ See, e.g., Pennsylvania v. Delaware Valley Citizens' Council, 106 S. Ct. 3088 (1986) (rejecting enhancement for superior quality of representation); City of Riverside v. Rivera, $106 \mathrm{~S}$. Ct. 2686 (1986) (holding that statutory fee award need not be proportional to low damage award); Evans, $106 \mathrm{~S}$. Ct. at 1531 (allowing plaintiff to waive $\$ 1988$ fee claim in settlement negotiations); Marek, $105 \mathrm{~S}$. Ct. at 3012 (discussing effect on fee awards of offer of settlement under Fed. Rule Civil Proc. 68); Blum v. Stenson, 465 U.S. 886 (1984); Hens- 
now authorize courts to award reasonable attorney's fees to prevailing parties, ${ }^{18}$ abandoning the traditional American Rule that litigants pay their own attorney's fees. ${ }^{17}$ The Civil Rights Attorney's Fees Awards Act of 1976, which encompasses most civil rights suits, provides that "the court, in its discretion, may allow the prevailing party, other than the United States, a reasonable attorney's fee as part of the costs."18

The Fees Act was Congress's direct response to Alyeska Pipeline Service Co. v. Wilderness Society, ${ }^{19}$ a section 1983 case in which the Supreme Court refused to adopt a broad common law or "private attorney general" theory of fee shifting and invited Congress to provide explicitly for fee shifting by amending the civil rights statutes. ${ }^{20}$ The Fees Act introduced fee shifting under the civil rights statutes, "touch[ing] off an explosion in civil rights cases."21 The broad purposes of the Act are captured best by the concern, expressed in both the Senate and House Reports, that "civil rights laws depend heavily upon private enforcement [and] the citizen who must sue to enforce the law has little or no money

ley v. Eckerhart, 461 U.S. 424 (1983); J. Leubsdorf, The Contingency Factor in Attorney Fee Awards, 90 Yale L. J. 473 (1981); Symposium, Attorney Fee Shifting, 47 Law \& ConTEMP. ProBs. 1-354 (Winter 1984); Comment, The Contingency Factor and the Attorney's Fees Awards Act of 1976: Legislative History Requires Continued Application, 26 SANTA Clara L. REv. 193 (1986); Note, Attorney Fees and the Contingency Factor Under 42 U.S.C. \& 1988: Blum v. Stenson, 465 U.S. 886 (1984), 64 ORE. L. REv. 571 (1986).

Attorney fee shifting is a particularly amenable topic to economic analysis See $R$. Braeutigam, B. Owen, \& J. Panzar, An Economic Analysis of Alternative Fee Shifting Systems, 47 Law \& Contemp. Probs. 173 (Winter 1984); G. Priest, Regulating the Content and Volume of Litigation: An Economic Analysis, 1 Sup. CT. Econ. Rev. 163 (1982); S. Shavell, Suit, Settlement, and Trial: A Theoretical Analysis Under Alternative Methods for the Allocation of Legal Costs, 11 J. Leg. Stud. 55 (1982); R. Posner, An Economic Approach to Legal Procedure and Judicial Administration, 2 J. Leg. Stud. 399 (1973); W. Landes, An Economic Analysis of the Courts, 14 J. L. \& Econ. 61 (1971).

${ }^{16}$ Jefrrey R. Goodstein, Attorney's Fees: Winning a Recovery in Federal Court (1985) (compiling statutes with fee shifting provisions); 8 Attorney Fee Awards Rep., No. 3 (June 1985) at 2-3 (listing 131 statutes providing for attorney's fee shifting).

${ }^{17}$ See Alyeska Pipeline Co. v. Wilderness Society, 421 U.S. 240, 247 (1975), in which the Supreme Court explained that "[i]n the United States, the prevailing litigant is ordinarily not entitled to collect a reasonable attorneys' fee from the loser." The Court declined to "fashion a far-reaching exception to this "American Rule."

1842 U.S.C. $\$ 1988$ (1982).

19421 U.S. 240 (1975).

${ }^{20}$ Id. at 269-71 (refusing to "invade the legislature's province" by extending attorney's fees award to statutes not expressly providing for them). For a general discussion of Alyeska, see Evans, $106 \mathrm{~S}$. Ct. at 1548-50 (Brennan, J., dissenting). See also Note, Judicial Discretion and the 1976 Civil Rights Attorney's Fees Awards Act: What Special Circumstances Render an Award Unjust?, 51 Fordham L. Rev. 320, 322-26 (1982).

21 Diamond, supra note 4,69 A.B.A. J. at 1420; see also NAAG REPORT, supra note 7, at 8-10. 
with which to hire a lawyer."22 Congress thus hoped to provide incentives for competent counsel to represent the poor, who would act as private attorneys general and thereby help deter civil rights violations. ${ }^{23}$ Congress also sought to discourage non-meritorious suits by authorizing courts to shift fees to prevailing parties, including defendants, rather than just to prevailing plaintiffs. ${ }^{24}$ In general terms, reasonable fees were described as those fees sufficient "to attract competent counsel in cases involving civil and constitutional rights, while avoiding windfalls to attorneys."25

These goals are easily stated, but courts have failed as yet to effect them through a coherent fee shifting system or a consistent definition of reasonable fees; ${ }^{26}$ without some degree of predictability, the incentive system Congress hoped to create cannot have ex ante effects on attorney behavior. ${ }^{27}$ Reacting to this state of confusion, the Supreme Court's recent decisions tend to limit the scope of courts' fee shifting discretion and to promote the consistency necessary to make fee awards a more effective incentive for the civil rights bar. ${ }^{28}$ At the same time, the Court has responded to the

22 S. REP. No. 1011 at 2, Source Book at 8.

2s See Comment, Attorney's Fees in Damage Actions Under the Civil Rights Attorney's Fees Award Act of 1976, 47 U. CHI. L. REv. 332, 344-48 (1980) (Fees Act embodies three public policy goals: to open the courts to civil rights plaintiffs otherwise unable to bring suit, to deter obstructive defense litigation tactics, and to deter civil rights violations by increasing defendant's costs of violating civil rights statutes).

${ }^{24}$ H. REP. No. 1558, at 6-7, Sounce BooK at 214-15. Then-Assistant Attorney General Rex E. Lee had expressed concerns that two-way fee shifting would create too much of a disincentive to plaintiffs. These fears were addressed in the reports by endorsing the Newman-Northcross standard (from Newman v. Piggie Park Enterprises, 390 U.S. 400 (1968) and Northcross v. Memphis Board of Education, 412 U.S. 427 (1973)), a dual standard of fee shifting whereby an unsuccessful plaintiff is assessed the defendant's fees only if the plaintiff acted in bad faith. S. REP No. 1011 at 4-5; see generally E. Richard Larson, Federal Court Awards of Attorney Fees 85-97 (1981).

${ }^{25} \mathrm{H}$. REP. No. 1558 at 6-7, Source BooK at 9; see also S. REP. No. 1011 at 6, Source Book at 12.

36 The resulting confusion has led one commentator to conclude that the "only truly consistent thread that runs throughout federal court decisions on attorneys' fees is their almost complete inconsistency." S. Berger, Court Awarded Attorneys' Fees: What is "Reasonable?", 126 U. PA. L. REv. 281, 292 (1977).

${ }_{27}$ See M. Breger, Compensation Formulas For Court Awarded Attorney Fees, 47 LAw \& Contemp. ProBs. 249, 258-59 (Winter 1984) (noting that incentives are a function of the likelihood of obtaining the fee award and suggesting that discretionary bonuses "cannot serve as an encouragement to take a case") (emphasis in original).

${ }^{28}$ See, e.g., Delaware Valley Citizens' Council, $106 \mathrm{~S}$. Ct. at 3088 (rejecting fee enhancement for superior quality of representation); Rivera, $106 \mathrm{~S}$. Ct. at 2694 (discussing relationship between low damage award and statutory fee award); Evans, $106 \mathrm{~S}$. Ct. at 1542 ("The unpredictability of attorney's fees may be just as important as their magnitude when a defendant is striving to fix its liability."); Blum, 465 U.S. at 898-900; Hensley, 461 U.S. at 433-34. See also Comment, Calculation of a Reasonable Award of Attorneys' Fees Under 
new burden of fee litigation by attempting to limit consideration of case-specific adjustment factors and to encourage out-of-court settlement. ${ }^{29}$

In its 1983 decision in Hensley v. Eckerhart, ${ }^{30}$ the Court established a uniform method for calculating fees and defined factors that might justify fees higher than the product of an attorney's hourly rate and the number of hours worked. In Hensley, the Court adopted a two-step "lodestar" calculation to determine reasonable fees. ${ }^{31}$ First, a reasonable hourly rate is multiplied by the hours spent: this figure is the "lodestar." Second, the lodestar is increased or decreased based on a court's consideration of twelve factors listed in Johnson $v$. Georgia Highway Express, Inc., ${ }^{32}$ which both houses of Congress endorsed by reference in their reports on the Fees Act. Illustrative Johnson factors include the novelty and difficulty of the questions presented by the case, the fixed or contingent nature of the fee, the results obtained, and the undesirability of the case. ${ }^{33}$

In addition to clarifying the methodology of fee calculation, the Hensley Court emphasized that Congress intended to shift only fees related to prevailing parties' meritorious claims, and thus it held that work on unrelated, unsuccessful claims was not compensable. ${ }^{34}$ The opinion stressed that "Congress has not authorized an award of fees whenever it was reasonable for a plaintiff to bring a lawsuit or whenever conscientious counsel tried the case with devotion and skill." 35 The Court also seemed to endorse one Johnson

the Attorneys' Fees Awards Act of 1976, 13 J. Mar. L. REv. 331, 377-82 \& nn. 234-36 (1980) (describing current fee practice as "chaotic" and noting wide variability (685 percent) in reasonable rates allowed in one district).

${ }^{29}$ See, e.g., Evans, $106 \mathrm{~S}$. Ct. at 1542 (allowing plaintiff to waive fees to encourage settlements and thereby avoid "forcing more cases to trial, unnecessarily burdening the judicial system, and disserving civil rights litigants"); Marek, $105 \mathrm{~S}$. Ct. at 3018 ("settlements rather than litigation will serve the interests of [civil rights] plaintiffs as well as defendants").

so 461 U.S. 424 (1983).

s1 Id. at 433-34.

s2 488 F.2d 714 (5th Cir. 1974).

${ }^{33}$ The twelve factors laid out in Johnson are as follows: (1) the time and labor required; (2) the novelty and difficulty of the questions; (3) the skill requisite to perform the legal services properly; (4) the preclusion of other employment by the attorney due to acceptance of the case; (5) the customary fee; (6) whether the fee is fixed or contingent; (7) time limitations imposed by the client or the circumstances; (8) the amount involved and the results obtained; (9) the experience, reputation and ability of the attorneys; (10) the "undesirability" of the case; (11) the nature and length of the professional relationship with the client; and (12) awards in similar cases. 488 F.2d at 717-19.

34 461 U.S. at 434-35.

ss Id. at 436. 
adjustment factor-the results obtained-since it vacated the fee award because the district court did not "properly consider the relationship between the extent of success and the amount of the fee award." 36 The Court indicated that upward adjustment for positive results should take place only in rare cases where the degree of success was truly exceptional, although it did not define "exceptional" success. ${ }^{37}$ In addition, while it affirmed the district courts' discretion in fee award decisions, the Court directed lower courts to explain clearly their fee calculations and the bases for enhancement. ${ }^{38}$ Thus, while approving courts' well-explained application of some Johnson factors, the Court demonstrated its determination to limit fee shifting to meritorious claims of prevailing parties. ${ }^{39}$

In Blum v. Stenson, ${ }^{40}$ the Court further refined the bases for lodestar enhancement ${ }^{41}$ and affirmed Hensley's requirement that lower courts clearly explain any adjustments to the lodestar figure. ${ }^{42}$ Blum held that neither the complexity nor the novelty of litigated issues was an appropriate basis for enhancing fee awards, thereby narrowing the class of cases in which Hensley's "exceptional success" standard could be used to justify fee enhancement. ${ }^{43}$ While rejecting the risk enhancement in Blum because the

${ }^{38}$ Id. at 438. See also Rivera, $106 \mathrm{~S}$. Ct. at 2691-92; Johnson, 488 F.2d at 717-19.

Courts have awarded fee enhancements for "results obtained" because "the case has significantly furthered the substantive purposes of 42 U.S.C. $\$ 1983$," Vecchione v. Wohlgemuth, 481 F. Supp. 776, 797 (E.D. Pa. 1979). See also LARson, supra note 24, at 135, 236-37. In arguing against a multiplier based on nonpayment risk, this comment does not suggest that the "results obtained" multiplier should be curtailed. While such a public policy multiplier encourages lawyers to bring cases that advance the law, a nonpayment risk multiplier may encourage lawyers to bring riskier cases, regardless of their effect on the law.

${ }^{37}$ Hensley, 461 U.S. at 435.

ss Id. at 437.

s9 Id. at 437-40. See also infra note 132 (discussing "prevailing parties").

10465 U.S. 886 (1984).

1 The Court qualified its approval of a multiplier based on "results obtained," holding that because this factor generally is subsumed within other factors used to calculate a reasonable fee, it normally should not provide an independent basis for increasing the fee award. Id. at 900. This reasoning, combined with language from Hensley suggesting the lower court "may simply reduce the award to account for the limited success," 461 U.S. at 437-8, indicates the Court views "results obtained" as a basis for reducing a fee award, but not for enhancing the lodestar other than in exceptional cases.

In Rivera the Court, holding that the findings of the District Court were not clearly erroneous, declined to reduce the fees awarded to account for the comparatively modest amount of damages. Rivera, $106 \mathrm{~S}$. Ct. at 2693. Nevertheless, the Court reaffirmed consideration of "results obtained," finding "[t]he amount of damages a plaintiff recovers is certainly relevant to the amount of attorney's fees to be awarded under $\S 1988$." Id. at 2694.

42 Blum, 465 U.S. at $900-901$ (district court's failure to identify its justification for the fee award and prevailing party's failure "to carry [its] burden of justifying entitlement to an upward adjustment" led Court to reverse lower court's fee enhancement).

is Id. at 897 . 
lower court failed to justify its award in the record, the Court expressly left open the question of whether the risk of not prevailing should ever justify such a fee enhancement. ${ }^{44}$

Both Hensley and Blum reflect the Court's growing impatience with attorney's fees litigation and its belief that a "request for attorney's fees should not result in a second major litigation."45 The Supreme Court's two most recent fees cases, City of Riverside v. Rivera ${ }^{46}$ and Pennsylvania v. Delaware Valley Citizens' Council, ${ }^{47}$ reflect several trends consistent with Hensley and Blum. In Rivera, without a majority opinion, five Justices rejected the notion that fees awarded under section 1988 must be proportional to the damages recovered in the underlying action. ${ }^{48}$ Significantly, the plurality continued to apply an abuse of discretion standard of review and thereby to encourage district courts to provide detailed explanations of fee awards. ${ }^{49}$ Since it refused to disturb the district court's finding that a fee award seven times greater than the amount of damages was reasonable, the Court may have both limited downward lodestar adjustments and discouraged appeals of fee awards. In Delaware Valley, a case appealed because the lower courts allowed upward adjustment for "superior work, outstanding result, and contingency," "so the Court did disturb the lower courts' findings. In emphasizing that quality of counsel should be reflected in reasonable hourly rates, the Court strengthened the presumption that the lodestar figure itself represents a reasonable fee ${ }^{51}$ and

11 Id. at $901 \mathrm{n.17}$ ("We have no occasion in this case to consider whether the risk of not being the prevailing party in a $\$ 1983$ case, and therefore not being entitled to an award of attorney's fees from one's adversary, may ever justify an upward fee adjustment."). See also Delaware Valley Citizens' Council, $106 \mathrm{~S}$. Ct. at 3100 (restoring case to docket for reargument on this issue).

4s Blum, 465 U.S. at 902 n.19 (quoting Hensley, 461 U.S. at 437). See also Hensley, 461 U.S. at 455-56 (Brennan, J., concurring in part, dissenting in part), where Justice Brennan assails Fees Act law as "a vast body of artificial, judge-made doctrine, with its own arcane procedures, which like a Frankenstein's monster meanders its well-intentioned way through the legal landscape leaving waste and confusion (not to mention circuit splits) in its wake." But for a skeptical judicial reaction, see Kirchoff v. Flynn, 786 F.2d 320, 325 (7th Cir. 1986) (finding the Supreme Court's desire to avoid second major lawsuits over fees to be "an unattainable dream"). Just as the "fuzziness" of the current criteria may increase incentives to litigate fee claims, clarifying the criteria and reducing the stakes involved in fee disputes should provide a significant disincentive for such litigation. Even if such disincentives are only steps towards "an unattainable dream," they should be taken.

18106 S. Ct. 2686 (1986).

17106 S. Ct. 3088 (1986).

Rivera, 106 S. Ct. at $2694-2700$.

4 Id. at 2693.

so Delaware Valley Citizens' Council v. Pennsyivania, 762 F.2d 272, 281 (3rd Cir. 1985).

${ }^{s 1}$ Delaware Valley Citizens' Council, 106 S. Ct. at 3098. 
heightened the showing required to demonstrate exceptional success "to the point where it may be virtually impossible for a plaintiff to meet."

In sum, the Supreme Court's recent fee award decisions represent a move toward a more standardized approach to fee calculation that provides more guidance to the lower courts and limits enhancement discretion to truly exceptional cases. By reducing the complexity and subjectivity of fee determinations, the Court hopes to encourage settlement rather than litigation of fee claims. ${ }^{63}$ To be sure, the Court has not yet directly considered nonpayment risk enhancement in these cases. But its express opinion that the issue is still left open despite near-uniform appellate court practice allowing enhancement demonstrates that it may have misgivings about the use of multipliers to compensate for the risk of nonpayment. ${ }^{54}$ The Court may well make this implication explicit when it addresses the issue during the 1986 term. $^{\text {s5 }}$

\section{B. Nonpayment Risk Multipliers in the Lower Courts}

Since Blum, seven of the nine circuits that have directly confronted the issue have upheld fee enhancement to compensate lawyers for bearing the risk of nonpayment as consistent with Congress's intent to provide reasonable attorney's fees. ${ }^{56}$ Wildman $v$. Lerner Stores, Inc. ${ }^{57}$ typifies this approach. In Wildman, defendants appealed an attorney's fee award that included a fifty percent upward adjustment due to the special difficulties of the case, counsel's "acute understanding of the law," and the "contingency of losing all their time and effort."

s2 Id. at 3100 (Blackmun, J., dissenting).

63 Hensley, 461 U.S. at 437 ("Ideally, . . . litigants will settle the amount of a fee.").

s4 For examples of this reading of the Court's recent decisions, see May v. Cooperman, 582 F. Supp. 1458, 1462-63 (D.N.J. 1984) (changing original decision to award nonpayment risk multiplier of 1.25 and rejecting any enhancement, arguing that the Blum decision severely circumscribes upward adjustment of the lodestar); S. Levin \& T. Grande, Attorneys' Fees Bonuses After Hensley and Blum, IB Fed. Litigator 42, 43 (1985).

ss Delaware Valley Citizens' Council, 106 S. Ct. at 3100 (restoring case to docket for reargument on nonpayment risk enhancement).

se See Crumbaker v. Merit Systems Protection Bd., 781 F.2d 191, 196-97 (Fed. Cir. 1986); Wildman v. Lerner Stores Corp., 771 F.2d 605 (1st Cir. 1985); Delaware Valley Citizens' Council v. Com. of Pa., 762 F.2d 272 (3rd Cir. 1985) aff'd in part, rev'd in part, and restored to docket sub nom. Pennsylvania v. Delaware Valley Citizens' Council, $106 \mathrm{~S}$. Ct. 3088 (1986); Kelley v. Metropolitan County Bd. of Educ., 773 F.2d 677 (6th Cir. 1985); LaDuke v. Nelson, 762 F.2d 1318, 1333 (9th Cir. 1985); Sierra Club v. Clark, 755 F.2d 608, 620 (8th Cir. 1985); Jones v. Central Soya Co., 748 F.2d 586, 591 (11th Cir. 1984).

s7 771 F.2d 605 (1st Cir. 1985).

ss Id. at 610 . 
After holding novelty and complexity of the issues as well as quality of counsel improper bases for enhancement, the First Circuit identified a host of factors under the rubric of contingent fee risks that might justify enhancement. Like many courts, the First Circuit turned "contingency" risks into a catch-all by blurring other Johnson factors-such as the preclusion of alternate employment and the size and undesirability of the case-and by calling them contingent fee risk factors. ${ }^{59}$ It reasoned that Congress must have intended upward fee adjustments for nonpayment risk, relying for evidence on the citation in the Senate Report of a case that employed a contingency bonus. ${ }^{60}$ Moreover, the court argued, without such nonpayment risk compensation, rational lawyers would never choose to take contingent fee cases, because they would be better off taking cases on full retainer. ${ }^{61}$

McKinnon v. City of Berwyn ${ }^{62}$ represents the strongest rejection of nonpayment risk bonuses. There the Seventh Circuit indicated that nonpayment risk compensation indirectly subsidizes lawyers who take unsuccessful suits and therefore contravenes Congress's explicit intent to limit attorney fee shifting to meritorious, prevailing claims. ${ }^{63}$ After concluding that the risk of losing

s8 Id. at 612. The Court also considered as compensable risks the possibility of nonreimbursement for expenses incurred on behalf of the plaintiff and the chance that a court would deem certain hours claimed as "duplicative, unnecessary, or inefficiently expended."

${ }^{60}$ Id. at 611-13 (citing Justice Brennan's concurring opinion in Blum and the citation to Stanford Daily in S. REP. No. 1011). Other courts of appeals have similarly relied on the cases cited by the Senate Report to resolve the nonpayment risk multiplier issue. See, e.g., Hall v. Borough of Roselle, 747 F.2d 838, 843 (3d Cir. 1984). Cf. Jones v. Central Soya Co., 748 F.2d 586, 593 (11th Cir. 1984), in which the court found that nonpayment risk enhancement is appropriate only when an attorney has an explicit agreement "to hold his client unaccountable for his fees if he loses the case." Note that, unlike the First Circuit in Wildman, both the Third and the Eleventh Circuits limited their consideration to factors relevant to nonpayment risk-the case's merits and the nature of any fee agreements. See, e.g., Jones, 748 F.2d at 593 (rejecting risk of nonpayment of non-contingent fee entitlement due to client's indigency, since that risk is "assumed without special compensation by all attorneys in all cases").

61 See Wildman, 771 F.2d at 612-13 (reasoning that since Congress did not intend to limit civil rights enforcement to pro bono lawyers and wealthy private attorneys general, fees without a compensation for the risk of nonpayment are not reasonable). See also Palmer v. Shultz, 594 F. Supp. 433, 441 (D.D.C. 1984); Williamsburg Fair Hous. Comm. v. Ross-Rodney Hous. Corp., 599 F. Supp. 509, 519-20 (S.D.N.Y. 1984).

${ }^{62} 750$ F.2d 1383 (7th Cir. 1984).

63 Id. at 1392. Judge Posner in McKinnon attempted to demonstrate the absurdity of a multiplier that was inversely proportional to the risk of losing by pointing out that a case with a 2 percent chance of winning would require a multiplier of 50 . He thus concluded that such a multiplier would encourage frivolous suits.

Judge Posner's argument has some force: multiplying a fee award in proportion to a case's riskiness gives greater incentives to bring risky suits (some of them frivolous) than 
does not justify fee enhancement, the court noted that the case for fee enhancement is particularly weak where the prevailing party has agreed to pay his lawyer a percentage of recovery or some other fixed sum. ${ }^{64}$

Staking out a middle ground, the D.C. Circuit has ruled that although some contingency multipliers are permissible, a multiplier derived by taking the reciprocal of a case's success probability to compensate attorneys for the risk of losing is contrary to Congress's intent. ${ }^{65}$ In Laffey $v$. Northwest Airlines, Inc. ${ }^{66}$ the court pointed out that a fully compensatory risk multiplier might lead "to a situation in which every conceivable claim would be litigated, subject only to the ability of the courts to handle the burden." The court also argued that the Hensley bar to fee shifting for work on claims unrelated to the successful portion of a suit should proscribe contingency multipliers that in effect compensate counsel for work on other losing cases. ${ }^{88}$

Nevertheless, the court did not rule out all contingency enhancements. ${ }^{68}$ Though the panel noted the Supreme Court had indicated "grave doubts" as to whether such adjustments should ever be made, it read Blum to imply that nonpayment risk enhancement may be appropriate in some cases of exceptional success. ${ }^{70}$ In stopping short of the Seventh Circuit's rejection of lodestar enhancement for nonpayment risk, the D.C. Circuit expanded the significance of the Blum "exceptional success" inquiry by permitting "results obtained" enhancement to reflect nonpayment risk.

does having no multiplier at all. But his conclusion that the multiplier of 50 would cause lawyers to favor a suit with a 2 percent chance of success is valid only on the assumption that the lawyer is risk-neutral or risk-preferring. If, rather, the lawyer is risk-averse, even a multiplier of 50 would be insufficient to compensate him for the 98 percent probability of nonpayment.

Quite apart from the validity of Judge Posner's unsupported assumption, his hypothetical points up the difficulties inherent in setting a nonpayment risk multiplier. Assessing the risk preference functions of lawyers is an exceedingly complex task. It is made even more difficult by the fact that there may be an absolute upper bound on how many losing cases a lawyer could afford to bring before winning one with a multiplied fee award. It is highly doubtful whether any branch of government-particularly the courts-accurately could make such determinations.

64 Id. at 1393 (Such an agreement "hedged the lawyer against the downside risk of a low damage award. He is not entitled to more insurance in the form of a risk multiplier.").

os Laffey v. Northwest Airlines, Inc., 746 F.2d 4, $26-27$ (D.C. Cir. 1984).

se 746 F.2d 4 (D.C. Cir. 1984).

Id. at 27.

s8 Id. at 27 \& n.138.

6. Id. at 28-29; see also Murray v. Weinberger, 741 F.2d 1423, 1431 (D.C. Cir. 1984).

${ }^{70}$ Laffey, 746 F.2d at 28-29. 


\section{The Case Against Contingency Compensation}

Confusion in the courts over attorneys' fees in general and nonpayment risk multipliers in particular makes it necessary to undertake a detailed analysis of the propriety of such multipliers under the Fees Act. The analysis in this section begins by reviewing the legislative history of the Act. After finding this history to be internally inconsistent and thus inconclusive on the issue, the section turns to an analysis of the policies implicated by fee enhancement for nonpayment risk. The section concludes that for reasons of policy, the Supreme Court should reject the use of nonpayment risk multipliers, whether they are determined case-bycase or formulated as an across-the-board multiplier applicable to all civil rights cases.

\section{A. The Legislative History: Is Stanford Daily Dispositive?}

Because the language of the Fees Act is ambiguous as to whether multipliers for risk of nonpayment are appropriate, courts and commentators have looked to the Act's legislative history for guidance. The evidence most frequently cited to support the use of multipliers is the Senate Report, which approvingly refers to several cases as examples of proper fee shifting practice. ${ }^{71}$ Because Stanford Daily v. Zurcher, ${ }^{72}$ which applied a contingency bonus, was one of these cases, courts often argue that Congress authorized contingency enhancements. ${ }^{73}$ There are several reasons, however, why the Senate Report references are not dispositive.

First, the Fees Act must be interpreted through both the Senate and the House reports, ${ }^{74}$ and the House report does not cite Stanford Daily or any case applying a nonpayment risk enhancement. ${ }^{75}$ The more authoritative case in determining whether non-

71 See S. ReP. No. 1011 at 6, Source Book at 12.

7264 F.R.D. 680 (N.D. Cal. 1974).

${ }^{73}$ See, e.g., Hall v. Borough of Roselle, 747 F.2d 838, 842-43 (3d Cir. 1984).

74 See C. Sands, 2A Sutherland on Statutory Construction $\$ 48.06$ (4th ed. 1984); H. REP. No. 1558 at 8-9, Source Book at 2. House consideration of S. 2278 followed Senate passage of the bill, and the House bill's sponsor announced that "it is intended that the courts will interpret S. 2278 in accordance with House Report No. 94-1558, together with the Senate report and debates in both Houses," 122 CoNG. REc. H12159 (1977), Source BooK at 254.

7s Both the Senate report and the House report endorse reasonableness standards laid out in Johnson, supra note 2. S. REP. No. 1011 at 6, H. REP. No. 1558 at 8, Source BooK at 12,216 . The House report does not cite Stanford Daily or any other case utilizing a contingency bonus; rather, the only factors it explicitly endorses are "the time and labor required, the novelty and difficulty of the questions involved, and the amount received in damages, if any." H. REP. No. 1558 at 8, Source BooK at 216. Hence, even assuming that the Senate's 
payment risk is an appropriate basis for fee enhancement is Johnson $v$. Georgia Highway Express, Inc., which is cited in both reports. ${ }^{76}$

Johnson cites twelve factors that courts should consider in determining whether a fee should be adjusted from the lodestar. ${ }^{77}$ Only one of these factors, the so called "contingency factor," is arguably related to nonpayment risk; and there is tremendous variation among circuits interpreting this factor. Some courts have read the Johnson "contingency factor" to mean that courts should consider the terms of any fee agreement only as an indicator of what the attorney expected, not as a separate justification to enhance reasonable fees. ${ }^{78}$ These courts adopt a literal reading of Johnson under which a contingent fee arrangement may be used only as a comparison or upper bound to the court's independent determination of a reasonable rate for a lawyer's services. ${ }^{79}$ Other courts have given the existence and terms of contingent fee contracts even less weight in determining a reasonable fee. ${ }^{80}$ Hence, the Johnson standard may contemplate narrow consideration of contingent fee agreements for comparison purposes but still not justify use of a nonpayment risk multiplier.

Second, even if one accepts the citation of Stanford Daily as indicative of Congress's intent, the rationale offered in that case for allowing contingency bonuses is impossible to reconcile with other statements of congressional intent in the Fees Act. In Stanford Daily, the district court awarded an enhancement because it

approval of Stanford Daily should be interpreted as a purposeful endorsement of contingency enhancements, the House's failure to cite a case employing a multiplier after the Senate had passed S. 2278 should at least raise some doubt as to whether the full Congress intended to endorse nonpayment risk bonuses.

${ }^{78}$ See, e.g., Kirchoff v. Flynn, 786 F.2d 320, 329 (7th Cir. 1986) (Eschbach, J., dissenting).

${ }^{77}$ See supra note 33.

7s In describing the sixth factor, the Johnson court noted that "[t] $t$ he fee quoted to the client or the percentage agreed to is helpful in demonstrating the attorney's fee expectations when he accepted the case." 488 F.2d at 718. In other words, fee agreements may serve to verify the reasonableness of fees awarded, but "the criterion for the court is not what the parties agreed to but what is reasonable." Id. at 718 (quoting Clark v. American Marine Corporation, 320 F. Supp. 709, 711 (E.D. La. 1970)).

70 Johnson, 488 F.2d at 718 ("In no event . . . should the litigant be awarded a fee greater than he is contractually bound to pay."). See also, e.g., In re Ill. Congressional Districts Reappor. Cases, 704 F.2d 380, 382 (7th Cir. 1983) ("[A] court may consider contingency in determining the reasonableness of a fee, but [contingency] does not in itself justify a multiplier."). With the elimination of nonpayment risk multipliers, courts could only consider the "contingency factor" as an indication of the maximum reasonable fee.

so See Kirchoff, 786 F.2d at 328 ("Several courts appear to say that contingent fees are irrelevant, impermissible, or both under $\S 1988 . ")$ (citations omitted). 
"insures that counsel are compensated not only for their successful efforts but also for unsuccessful litigation." ${ }^{81}$ But the statutory limitation to "prevailing parties"82 indicates, and the Court in Hensley explicitly found, that Congress had authorized fee shifting only for successful claims. ${ }^{83}$ This limitation cannot be squared with Stanford Daily's intent to generate a pool of fee awards to compensate lawyers for all cases brought.. ${ }^{84}$

Courts awarding contingency bonuses have failed to address this fundamental inconsistency. A contingency bonus "compensates attorneys, indirectly but effectively, for bringing unsuccessful civil rights suits, even though the attorney's fee statute is expressly limited to cases where the party seeking the fee prevails."85 If this indirect subsidization exists, it conflicts with Congress's intent whether the multiplier is 50 or $1.2 .{ }^{86}$ The Senate report's reference to Stanford Daily thus creates a direct conflict within the legislative history. Because of the ambiguity in both the language of the Fees Act and its legislative history, courts should proceed to consider contingency enhancements in terms of the broader purposes of the Fees Act and the incentive effects of nonpayment multipliers..$^{87}$

\section{B. Multipliers Based on Case-Specific Risks of Nonpayment: A Policy Analysis}

One way to assess nonpayment risk multipliers-and the way currently used by the courts-is on a case-by-case basis: the court examines the risks of the specific case to determine whether to apply a multiplier. This section demonstrates the problems inherent in such an approach. Case-by-case determination tends to penalize

81 Stanford Daily, 64 F.R.D. at 685.

${ }^{82}$ See supra note 1.

ss Hensley v. Eckerhart, 461 U.S. 424, 435-36 (1983).

${ }^{84}$ Laffey, 746 F.2d at 28 . Commentators have also noted that application of the contingency multiplier where there are fee agreements between a plaintiff and her attorney is inconsistent with Congress's desire to prevent windfalls to attorneys. See, e.g., Comment, Calculation of a Reasonable Award of Attorneys' Fees Under the Attorneys' Fees Awards Act of 1976, 13 J. Mar. L. REv. 331, 370-71 (1980).

${ }^{8 s}$ McKinnon v. City of Berwyn, 750 F.2d 1383, 1392 (7th Cir. 1984).

se In Wildman v. Lerner Stores Corp., 771 F.2d 605, 612-13 (1st Cir. 1985), the court challenged Judge Posner's analysis in McKinnon for failing to consider how relatively modest multipliers have been. But attacking "the McKinnon spectre of bonus multipliers amounting to fifty" merely demonstrates that Judge Posner chose an extreme example to demonstrate his point. Whatever the size of the multiplier, it contradicts the statutory language and congressional intent if it results in any indirect subsidy to non-prevailing parties.

${ }^{87}$ See SANDS, supra note 74 , at $\$ \S 45.09,48.01,48.06$ n.3. 
defendants in inverse proportion to the egregiousness of their violations; in addition, it creates expensive litigation over fee multipliers without providing clear standards that would tend to reduce the incentives of parties to litigate such questions.

Before examining these problems, however, it should be emphasized that this inquiry is limited to factors that directly affect an attorney's risk of nonpayment. Courts have tended to blur the definition of "contingency multipliers," justifying them by reference to a host of factors unrelated to nonpayment risk. Although they often are cited to justify "contingency multipliers," factors such as the size of a case, ${ }^{88}$ its "intensity," and the risk of payment delay ${ }^{91}$ either do not affect the probability

ss See Johnson, 488 F.2d at 718 (eighth factor); LARSon, supra note 24, at 220-21 ("Most courts, when analyzing the contingency factors, place primary weight on the fact that the litigation was hard fought or protracted."); MARY DERPNER \& ALAN Wolp, CourT AWARDED ATTORNEY's FeEs $\$ 16.04$ [2]c[ii] (1983) (noting that courts generally have held that risk factor enhancement should be larger the more time consuming the case). Thus, one of the primary contingency factors has been the magnitude of the stakes, or how much time and expense an attorney invested in the case when the only hope for a return was courtordered fee shifting. This emphasis on how much the lawyer puts at risk is one reason that contingency multipliers have generally been higher in antitrust, securities, and class action litigation than in public interest civil rights litigation. See Wildman, 771 F.2d at 613.

so See Johnson, 488 F.2d at 717-19 (fourth and seventh factors). This intensity factor is often cited in cases to justify a contingency bonus. It is based on preclusion of other work that may result when one takes on attorney fee shifting cases. See LARSon, supra note 24, at 224-25 (citing cases). The underlying rationale for upward adjustment is that some especially time-intensive cases may require a lawyer's full attention and thus preclude other work. While this has intuitive appeal, it may not make economic sense. Imagine two lawyers who have invested two months of their billable time to the same case where one has done all of his work in a two month span and the other spaced his work out over the course of a year. It is not at all clear that these two lawyers should be compensated at different rates. The market rate should reflect a lawyer's opportunity wage, as well as the cyclical nature, if any, of her practice.

90 See, e.g., Jones v. Federated Dept. Stores, Inc., 527 F. Supp. 912, 915-18 (S.D. Ohio 1981) (awarding single multiplier based upon the risk of nonpayment and "the undesirability of Title VII litigation in general"). The undesirability factor in Johnson is justified because attorneys "face hardships in their communities because of their desire to help the civil rights litigant. Oftentimes their decision to help eradicate discrimination is not pleasantly received by the community or their contemporaries." Johnson, 488 F.2d at 719 (citations omitted). See also LazSON, supra note 24, at 225-26; Derfner \& Wolr, supra note 88, at If 16.03[12]c. Since undesirability seems much more prevalent in civil rights suits than in other types of cases involving attorney fee shifting, there are strong arguments in favor of adopting a "public policy" multiplier. But policy multipliers should be established by the Congress, or should at least be explicit and not concealed as a factor in contingency bonuses. Accord Blum v. Stenson, 465 U.S. 886, 895-96 (1984) ("The policy arguments advanced in favor of a [different] standard should be addressed to Congress rather than to this Court.").

"1 See, e.g., Shaw v. Library of Congress, 747 F.2d 1469, 1472-73 (D.C. Cir. 1984), rev'd sub nom. Library of Congress v. Shaw, 106 S. Ct. 2957 (1986) (on grounds that increased multiplier on the basis of payment delay would amount to a waiver of the federal government's traditional immunity to payments of interest); Laffey v. Northwest Airlines, Inc., 32 
of payment or are better thought of as public policy enhancement factors with rationales independent of nonpayment risk. While there are strong arguments to adjust fees for each of these factors, here the focus is on those factors with a direct impact on an attorney's risk of nonpayment: (1) the fee agreement with the client; (2) the quality of the opposition; and (3) the merits of the case.

1. The Fee Agreement. In assessing the nonpayment risks a lawyer bears, one must first examine the agreement the lawyer has with her client. Assume two identical Section 1983 cases are brought, one against $X$ by an attorney representing a client agreeing to pay a guaranteed hourly rate and the other against $Y$ on behalf of a second client by an attorney whose fees are contingent upon prevailing. If contingency bonuses are meant to compensate lawyers for bearing the risk of nonpayment, a nonpayment risk multiplier obviously should be applied against $Y$ but not against $X$. Yet, the courts are at odds in their reaction to this simple reasoning; some do not consider contingent fee agreements in setting reasonable fees, while others give them considerable weight. ${ }^{92}$

This inconsistency is attributable to four troubling aspects of awarding fee enhancements based on the existence or terms of a contingent fee contract. The first source of confusion, discussed by the Seventh Circuit in Kirchoff $v$. Flynn, ${ }^{93}$ is that section 1983 cases may involve claims for injunctions, damages, or both. Each type of case calls for a different fee calculation, because the market for legal services has provided "different methods of calculating compensation in different kinds of cases." 94 Thus, a contingent fee contract might provide strong evidence of reasonableness in cases brought to enforce precedents through monetary damages. But it would give no indication of the appropriate fee in cases with primarily injunctive or precedent-creating motivations, which cannot be reduced to monetary terms.95 It may be difficult for a court to

FEP Cases 750 (D.D.C. 1983), aff'd in part, remanded in part, 746 F.2d 4 (D.C. Cir. 1984); LARSON, supra note 24, at 226-27; DERFNER \& WOLF, supra note 88, at If 16.04[2]d.

${ }^{92}$ See Kirchoff v. Flynn, 786 F.2d 320, 328 (7th Cir. 1986) (providing exemplary case citations and noting that treatments of contingent fee contracts "in other circuits give a mixed picture at best"). Cf. Hamner v. Rios, 769 F.2d 1404 (9th Cir. 1985) (prevailing party ordered to pay difference between contingent fee agreement and statutory award) with Pharr v. Housing Authority of City of Prichard, 704 F.2d 1216 (11th Cir. 1983) (requiring losing defendant to pay this difference).

23 786 F.2d 320 (7th Cir. 1986).

\% Id. at 328.

${ }^{95}$ Id. While the reasoning of the Kirchoff majority seems correct, it must be noted that in practice this system will add yet another layer of complexity in fee determinations by forcing courts to take a weighted average of the lodestar result and the contingent fee 
characterize which type of case is involved, or if a mix of relief is sought, to weigh the relative importance of each type.

Even in damage suits brought under section 1983, however, courts ought to disregard the terms of contingent fee agreements. The second troubling aspect of enhancing fees based on the terms of contingent fee agreements stems from the difference between typical contingent fee contracts and section 1988 contingent fee contracts. Unlike the normal contingent fee contract, section 1988 contingent fee contracts do not better align the interests of the plaintiff and the lawyer: the plaintiff has no real interest in the attorney's fee award, since if anyone has to pay the award, it will be his opponent. ${ }^{96}$

Third, if courts permit plaintiff-attorney fee agreements to influence reasonableness determinations, they will create strong incentives to engage in strategic contracting. For instance, if courts bar any claim for risk multipliers when a non-contingent fee contract is found, plaintiffs' attorneys will have incentives to conceal fixed-fee contracts, to engage in less formal non-contingent agreements, or to demand contingent fee contracts that they normally would not want. In creating an incentive to preserve contingency enhancement claims through concealment, courts may add to their attorney's fee caseload both by spawning new arguments over the existence of fee agreements and by adding fee enhancement to the parties' stakes in litigation. ${ }^{97}$

Similarly, using the terms of a contingent fee agreement as evidence of reasonableness creates incentives for the plaintiff and her lawyer to engage in another type of strategic contracting: inflating the agreed upon percentage. When two parties make an agreement that benefits one at the expense of an unrepresented third party (the defendant), there are unequivocal incentives to increase the liability of that third party. ${ }^{98}$

Fourth, even in the absence of any strategic actions by the parties, a fee contract may not necessarily reflect a reasonable determination of the nonpayment risk of a particular case. The specific terms of a contract between a plaintiff and her attorney are evidence of how much it is worth to the plaintiff to win the suit, but they do not necessarily demonstrate risk of nonpayment. If the

amount whenever cases have both injunctive and damage components.

98 Id. at 323.

${ }^{97}$ Cf. Priest, supra note 15, $1 \mathrm{~S}$. Ct. Econ. Rev. at 166 (increasing the stakes in litigation enhances incentives to litigate).

${ }^{98}$ Kirchoff, 786 F.2d at 323 n.4. 
plaintiff agreed to pay ninety percent of her recovery to her attorney for a type of suit that normally would be brought under a forty percent contingency agreement, one would expect the ninety percent figure to be more indicative of the extreme riskiness of the litigation, or the plaintiff's strong desire to litigate, than the reasonable market rate for the attorney's services. ${ }^{99}$ Thus, if there is any argument for using a percentage of recovery calculation, an average contingency percentage would seem more appropriate than a rate extrapolated from a case-specific agreement that might be influenced by other factors. ${ }^{100}$

Thus, reliance on the plaintiff's agreement with her attorney creates a significant potential for impermissible attorney windfalls that will, unfairly, come out of the pockets of the defendant, who has no influence over the terms of the agreement. ${ }^{101}$ The defendant has no control over whether the plaintiff or her attorney bears the risk of not winning attorney fees. One could argue that courts have already been too generous in interpreting the Fees Act to allow plaintiffs to recover attorney's fees in cases in which plaintiffs take the risk upon themselves by agreeing to pay their attorney, win or lose. ${ }^{102}$ If the existence or terms of a contingent fee contract justify enhancement of the lodestar amount, this generosity could be still more overdone.

Reliance on contingent fee contracts in determining reasonable fees thus entails difficulties in characterizing the relief the plaintiff seeks, errors in risk measurement because of strategic con-

90 Id. at 323 ("There is nothing magical about the percentage when the plaintiff expects the defendants to pay the freight.").

${ }^{100}$ A further complication arises, however, when one tries to determine from which market to draw that contingent-fee percentage. One could argue that each case is itself a market and the market rate percentage is that which the average lawyer would charge for that case. Obviously, such an approach is impractical, but relying on the historical market percentage for section 1983 cases or analogies to tort practice is rife with problems. See Kirchoff, 786 F.2d at 323; infra notes 118-34 and accompanying text. There simply is no average case or average percentage charged under section 1988 derivable from past experience, nor is the analogy to tort practice a good one.

${ }_{101}$ See Barrett v. Kalinowski, 458 F. Supp. 689, 708 (M.D. Pa. 1978) (reducing lodestar where plaintiff was represented by legal services organization because defendant would be unjustly penalized if forced to bear plaintiff's market rate fees); T. Rowe, Jr., The Legal Theory of Attorney Fee Shifting: A Critical Overview, 1982 Duke L. J. 651, 675 (1982) (noting that punishment or incentive rationales do not support an award of contingency bonuses and that "treating the defendant differently simply because the plaintiff chooses a different financing agreement with his lawyer seems unjust").

102 The Fees Act's emphasis on ensuring access for the poor need not have been stretched to cover cases brought under fixed fee agreements. But see Stanford Daily, 64 F.R.D. at 686 (allowing fee award despite fixed fee agreement of $\$ 8,500$, where amount guaranteed was only a fraction of total fees). 
tracting, and costs arising from both unfairness to defendants and an unnecessarily generous interpretation of the Fees Act. Further, contingent fee agreements should not be used to set reasonable fees because the benefits of some contingent fee agreements-eliminating the need for monitoring by better aligning attorney and client interests-are not present where the plaintiff is bargaining away the defendant's interests, not her own.

2. Quality of the Opposition. The second nonpayment risk component cited to justify fee enhancement is the nature of the opposition. ${ }^{103}$ Clearly, the more skillfully a suit is defended, the greater is the risk to the plaintiff's attorney of not prevailing; so a true nonpayment risk multiplier should increase with the quality of defendant's counsel. But to reward the plaintiff's attorney for bearing quality-related risks effectively penalizes defendants for obtaining high quality legal counsel and vigorously defending their positions. ${ }^{104}$ It may be that this incremental disincentive to obtaining higher quality legal counsel will have but a minimal effect on defendants' litigation decisions. But one nevertheless is hard pressed to find a rationale in the Fees Act for providing any disincentives (however small) for robust defenses. ${ }^{105}$

3. The Merits. The third component of nonpayment risk is the strength of a case's legal merits. In assessing the merits for contingency enhancement purposes, courts have considered such

${ }^{103}$ See, e.g., Danny Kresky Enterprises Corp. v. Magid, 716 F.2d 215, 220 (3d Cir. 1983) (remanding for lower court to consider enhancement where solo practitioner achieved success against "extremely competent" opposing counsel); Taylor v. Jones, 495 F. Supp. 1285, 1297 (E.D. Ark. 1980) (enhancing lodestar 20 percent for, among other factors, overcoming "tenacious opposition"); DERFNER \& WoLF, supra note 88, at I 16.04[c]iii (noting that nature of opposition, including skill of opposing counsel and tenacity of representation, has been one of the most widely used criteria for contingency enhancement). Derfner and Wolf note that courts are split on the question of whether opponents' fees and time spent are relevant in determining the reasonableness of plaintiff's lawyer fees. Id. at T 16.03[b] (citing cases).

104 Note that the differential between the quality of the plaintiff's lawyer and the quality of the defendant's counsel, rather than the absolute quality of the defendant's lawyer, may be the more accurate component of nonpayment risk. As might be expected, however, no case has been found in which the plaintiff's lawyer's lack of skill was cited as a basis for fee enhancement. The Supreme Court has eliminated fee enhancement based on the high quality of the plaintiff's representation, absent a showing that the skill of counsel is not reflected in the lawyer's hourly rate. Pennsylvania v. Delaware Valley Citizens' Council, 106 S.Ct 3088, 3099 (1986), rev'g (in part) 762 F.2d 272 (3d Cir. 1985). See also Blum v. Stenson, 465 U.S. 886, 898-99 (1984).

${ }^{103}$ It may be, however, that since fee shifting against defendants once the suit has begun increases defendants' stakes and thus their incentives to litigate, this incremental disin- centive to obtaining high quality counsel serves to counter-balance the general disincentives to settle inherent in an essentially one-way fee shifting system. 
factors as the legal and factual complexity of the case, whether liability hinges on precedents or novel interpretation of case law, and the burden of proving damages or the elements of the claim. ${ }^{106}$

Although the merits of a case are theoretically vital in assessing nonpayment risk, they cannot sensibly be evaluated on a caseby-case basis. Previous commentators have exposed many of the practical problems created by such retrospective evaluation of a case's merits. ${ }^{107}$ First, arguing over a case's riskiness creates a conflict of interest between the lawyer, who wants a high nonpayment risk multiplier, and her client, who prefers to have any weaknesses of his case unexposed. Courts should not provide "a direct incentive to lawyers to raise their fees by attacking [at a fee hearing] the strength of their clients' claims."108 Further, a judge should not be asked to evaluate the prevailing party's ex ante likelihood of success in a case the judge has just decided. In addition to the practical difficulties inherent in such an inquiry, it is both absurd and unseemly to ask a judge to determine the probability that he would have decided the case incorrectly. ${ }^{109}$

Even more important, awarding higher fee enhancements as the probability of winning decreased would be unfair to defendants and would create perverse incentives for plaintiff's attorneys. Such a nonpayment risk multiplier would force the least culpable defendants to pay higher attorney's fee awards than the most egregious offenders. ${ }^{110}$ It also would diminish the ordinary incentives for lawyers to prefer strong cases, skewing their preferences toward less meritorious claims. ${ }^{111}$ Indeed, providing such incentives to bring risky cases may well be inconsistent with the intent of Rule 11 of the Federal Rules of Civil Procedure, which was amended in

${ }^{108}$ See, e.g., Palmer v. Shultz, 594 F. Supp. 433, 440-41 (D.D.C. 1984).

${ }_{107}$ See Leubsdorf, supra note 15, 90 YALE L. J. at 482-92.

${ }^{108} \mathrm{Id}$. at $483-84$ (pointing out that such conflicts of interest are particularly problematic where the case may still go through further stages, such as an appeal).

${ }^{100} \mathrm{Id}$. at $485-88$ (once a case has been decided, and assuming that a judge considers the outcome to be the correct one, few judges would want to rule that the chances of another judge arriving at the same decision were less than 50 percent).

${ }^{110}$ See, e.g., Kirchoff, 786 F.2d at 326; Laffey, 746 F.2d at 26 \& n.134; Prandini v. National Tea Co., 557 F.2d 1015, 1020 (3d Cir. 1977) (noting that "the penalty fastened on the defendant would vary in inverse proportion to the strength of the case against him"); Leubsdorf, supra note 15, 90 YALE L. J. at 488-91; Breger, supra note 27, 47 LAW \& ConTEMP. Probs. at 260 n.70.

${ }^{11}$ Laffey, 746 F.2d at 27 n.138; see also Leubsdorf, supra note 15, 90 Yale L. J. at 49193. Of course, one could imagine a case whose merits are strong but whose evidence is weak. A multiplier that provided an incentive for nonpayment risk thus might vindicate a case against an egregious defendant that might not otherwise be brought. 


\section{3 to strengthen sanctions against frivolous lawsuits. ${ }^{112}$}

Analysis of a lawyer's risk of nonpayment is further complicated by the impracticability of determining accurately the combined effects of the three factors just discussed: non-contingent fee agreements, the quality of defense counsel, and the merits of the case. ${ }^{113}$ Moreover, each nonpayment risk component changes at different stages of a case. For example, each offer of settlement significantly changes the risk of nonpayment for future time spent, since the plaintiff may bear any attorney's fees incurred after a settlement offer that exceeds the eventual judgment..14 Even assuming that these probabilities could be determined accurately, ${ }^{115}$ one must ask how much of lawyers' and courts' time should be devoted to such fine-tuned inquiries that may only remotely advance the underlying purposes of the civil rights laws. As the volume and complexity of attorney's fee litigation have increased, courts have become increasingly concerned about the use of scarce judicial resources to resolve attorney's fee requests. ${ }^{116}$ The use of contingency multipliers only adds to this misallocation of judicial resources.

112 FED. R. Crv. P. 11; see also Advisory Committee Notes on Amendment (1983). Cf. the resulting anomalies described in In re Agent Orange Product Liability Litigation, $611 \mathrm{~F}$. Supp. 1296, 1311 (D.C.N.Y. 1985).

113 For an example of the court's attempts to analyze these three factors together, see National Ass'n of Concerned Vets. v. Secretary of Defense, 675 F.2d 1319, 1328 (D.C. Cir. 1982) (per curiam).

114 See Marek v. Chesny, 105 S. Ct. 3012, 3017 (1985) (holding that attorneys' fees are within the scope of Rule 68 "costs" and thus shift to the plaintiff after an offer of settlement that exceeds the eventual judgment). Many cases have recognized that different stages, most notably the fee litigation stage, call for different fee awards treatment. See those cited in DERFNER \& WoLF, supra note 88, at I 16.03[10] \& nn.126-29.

116 If the probabilities of success could be determined with any precision, one would expect to see highly variable fees in the personal injury contingent fee cases. Yet in reality, contingent fee practitioners have adopted standard percentage fees falling in a narrow range of 30 to 40 percent. Since there is no evidence that attorneys themselves scale-or even could scale-the percentage charged based on probabilities of success, it makes little sense to require courts to attempt it after the fact. See, e.g., Leubsdorf, supra note 15, 90 YaLE L. J. at $491 \&$ n.85.

116 See, e.g., Hensley, 461 U.S. at 454-55 (1983) (Brennan, J., concurring in part, dissenting in part) (noting that attorney's fee appeals vindicate no one's civil rights and take up judicial resources that could better be spent on "the substantive civil rights claims that \$ 1988 was meant to facilitate," and observing that appeals from fee awards "must be one of the least socially productive types of litigation imaginable"); Ashton v. Pierce, 580 F. Supp. 440, 444 (D.D.C. 1984) (noting that fee requests often "consume more time and involve more paperwork than the underlying case"). See also Marek, $105 \mathrm{~S}$. Ct. at 3018 (1985) (finding Rule 68's policy of encouraging settlements by shifting costs onto a plaintiff who refuses an offer of settlement "consistent with policies and objectives of $\S 1988$ "); Blum, 465 U.S. at 902 n.19 (1984) (noting that the court has responsibility to encourage fee agreement rather than "a second major litigation"). 


\section{The Across-the-Board Contingency Multiplier: A Tenable Solution?}

The simplest approach that still 'would retain contingency multipliers would be to adopt an across-the-board risk multiplier to enhance every section 1988 fee award. This alternative has been suggested by several commentators. ${ }^{117}$ An across-the-board multiplier would avoid many of the problems involved in case-by-case nonpayment risk compensation. It would eliminate defendants' incentives to litigate over the size of the multiplier and thus would save both courts' and litigants' resources, and it would end the unfairness of charging higher legal fees against marginal offenders than against egregious ones. In addition, judges no longer would face the awkward task of assessing success probabilities for cases they already had decided.

Across-the-board multipliers may, however, entail other significant costs: uniform risk compensation will be overinclusive and may thus result in windfalls. ${ }^{118}$ In addition, the current system of case-by-case determinations probably comports better with the intent of the Congress that passed the Fees Act than would a judicially-created across-the-board multiplier. If Congress had intended the Fees Act to include an across-the-board multiplier, it easily could have written one into the statute. Setting a multiplier to apply across the board is a legislative rather than a judicial function, requiring considerable empirical investigation and a sensitive balancing of competing interests.

In addition, two arguments applicable to multipliers in general counsel against the adoption of even a simple across-the-board multiplier. First, the use of nonpayment risk multipliers in Fees

117 See, e.g., Leubsdorf, supra note 15, 90 YALE L. J. at 510-14 (suggesting adoption of across-the-board multiplier of 2 to ensure that all cases with a greater than 50 percent chance of winning will be brought); Comment, Attorney Fees and the Contingency Factor Under 42 U.S.C. \& 1988: Blum v. Stenson, 465 U.S. 886 (1984), 64 ORE. L. REv. 571, 588-592 (1986). Contra Kirchoff, 786 F.2d at 328 (suggesting different approaches in damages and injunctive cases).

118 For example, if a multiplier of 2 were adopted, all those cases that would have been brought at rates less than two times the lodestar would be overcompensated. Obviously, lawyers who could successfully identify cases with greater than 50 percent success probability would earn windfall profit rates in excess of the market rate for their portfolios of cases.

Given Congress's evident intent not to encourage a flood of claims, it is unlikely that it would want to encourage even every civil rights claim with a 50 percent chance of success. Certainly, the courts have not defined "meritorious" so liberally: multipliers as high as 2 are extremely rare in civil rights cases. See Wildman, 771 F.2d at 613 (noting that only three reported cases in five years had given such a multiplier). 
Act litigation does not have a sound theoretical basis. Second, many attorneys already have sufficient incentives to take civil rights cases, in particular because market rates and hours claimed probably include compensation for nonpayment risk.

1. The genesis of "contingency multipliers." The use of contingency fees is particularly common in tort practice and common fund cases that allow attorneys a percentage of a plaintiff's recovery regardless of whether that percentage amounts to a very high hourly rate. ${ }^{119}$ The theoretical justification for contingency compensation in these cases is that without some compensation for risk of nonpayment, a rational risk-neutral lawyer would never choose to take a contingent fee case, because her risk-discounted expected return would be lower than if she worked at an hourly rate.

But one should not casually apply the contingency fee rationale developed in the tort and common fund areas to section 1988 attorney fee award litigation, for there are significant differences between the practices. ${ }^{120}$ First, there is strong reason to suspect that reasonable fee determinations under section 1988-hourly rates times hours spent-have an upward bias. ${ }^{121}$ With fee awards based on hours worked, rather than damages recovered, for example, plaintiff's attorneys have incentives to run up hours. ${ }^{122}$

${ }_{110}$ See, e.g., Lindy Bros. Bldrs., Inc. v. American R. \& S. San. Corp., 487 F.2d 161, 168 (3d Cir. 1973) (antitrust, common fund); Stanford Daily v. Zurcher, 64 F.R.D. 680, 686 (N.D. Cal. 1974) (discussing contingent fee doctrine and noting that its genesis was in percentage of damage cases, but that "the genesis of the doctrine does not preclude its use [in injunctive cases, where] the court retains the authority to order defendants to pay for the value of plaintiff's legal services"). See also Jones v. Diamond, 636 F.2d 1364, 1382 (5th Cir. 1981) (en banc) (finding compensation for risk "neither less nor more appropriate in civil rights litigation than in personal injury cases"); NAAG REPORT, supra note 7, at 32, 35), reprinted in EQUITY ACT HEARINGS I at 285, 288 ("The roots of [the contingency multiplier] can be found in the contingent fee agreements that often obtain betwen [sic] tort plaintiffs and their attorneys.").

${ }^{120}$ See, e.g., City of Riverside v. Rivera, 106 S. Ct. 2686 (1986). In Rivera, although both a concurrence and a dissent took issue with the majority's decision, the Court was unanimous in rejecting "the importation of the contingent-fee model to govern fee awards under $\S 1988$," id. at 2705 (Rehnquist, J., dissenting on other grounds), and holding that section 1988 fees should not be calculated as a percentage of damages, as in personal injury cases. Id. at 2694-97 (majority opinion), 2700 (Powell, J., concurring), 2705 (Rehnquist, J., dissenting). See also Kirchoff, 786 F.2d at 323-24 (section 1983 litigation is riskier and involves lower stakes than personal injury suits); May v. Cooperman, 582 F. Supp. 1458; 1463 (D.N.J. 1984) (unlike common fund doctrine, "'a reasonable fee under $\S 1988$ reflects the amount of attorney time reasonably expended on the litigation' ") (quoting Blum, 465 U.S. at 900 n.16); R. Fioretti \& J. Convery, Attorney's Fees Under the Civil Rights Act-A Time For Change, 16 J. MAR. L. REv. 261, $277-78$ (1983) (contrasting tort lawyers' incentives to settle with civil rights lawyers' incentives to run up hours).

${ }^{121}$ See infra notes 136-47 and accompanying text.

122 Fioretti \& Convery, supra note 120, 16 J. MAR. L. REv. at 277-78. 
Second, in a tort or a common fund case there is a contractual basis for ordering the plaintiff to pay a percentage of damages, a basis that is absent when it is the defendant who is compelled to pay fees. Tort plaintiffs pay their lawyers premium rates if they win damages, implicitly agreeing to cross-subsidize their lawyers' unsuccessful cases. ${ }^{123}$ In civil rights cases, however, defendants have made no comparable agreement. Imposing costs on defendants therefore is unfair unless they can spread the premium fee costs onto the beneficiaries of civil rights enforcement. ${ }^{124}$ But in many cases to which section 1988 applies, the defendants are individual state officials, sued in their personal capacity, who cannot pass the extra costs onto the beneficiaries of private civil rights enforcement, the public. ${ }^{128}$ In personal capacity suits, for instance, it seems unfair to penalize a defendant by charging him for the time the plaintiff's attorney has spent losing claims against other parties in unrelated cases. ${ }^{\mathbf{2 6}}$

${ }^{223}$ This is also arguably true of common fund and other class actions for which contingency multipliers have been awarded to attorneys. Members of the class who stand to benefit from litigation, yet are unwilling to take the financial risks of losing the suit, also implicitly agree to pay their class attorneys out of their winnings-the common fund. See Leubsdorf, supra note 15, 90 YALE L. J. at 476-77, 489.

${ }^{124}$ See, e.g., Hall v. Cole, 412 U.S. 1, 8-9 (1973) (defendant union required to pay for the vindication of union democracy through payment of plaintiff's fees); Leubsdorf, supra note 15, 90 YALE L. J. at 489. Here, government funds could be used in a nonpayment risk compensation pool from which nonpayment risk enhancements would be awarded. It has been argued, however, that the resultant strain on municipal treasuries would be inconsistent with congressional intent. See Fioretti \& Convery, supra note 120, 16 JoHN Marsh. L. REv. at 284.

${ }^{125}$ See, e.g., Kentucky v. Graham, 105 S. Ct. 3099, 3104 (1985) (requiring Court "to unravel once again the distinctions between personal and official capacity suits" under § 1983).

${ }^{128}$ See, e.g., Laffey v. Northwest Airlines, Inc., 746 F.2d 4, 27 n.138 (D.C. Cir. 1984), citing Leubsdorf, supra note 15, 90 YALE L. J. at 489; Ursic v. Bethlehem Mines, 719 F.2d 670, 677 (3d Cir. 1983) (defendant has not violated any duty to plaintiff's attorney, and purpose of fee awards is not to allow attorneys to benefit from defendant's wrong to plaintiff); City of Detroit v. Grinnell Corp., 560 F.2d 1093, 1101 (2d Cir. 1977) (expressing "“considerable doubt about the justice of charging members of one class higher fees to compensate counsel for failing to recover for another class," "quoting Liebman v. J.W. Petersen Coal \& Oil Co., 63 F.R.D. 684, 697 (N.D. Ml. 1974)). See also Derfner and Wolf, supra note 88, at $\Uparrow 16.04[2] \mathrm{b}$ n.32; Leubsdorf, supra note 15, 90 YALE L. J. at 489.

In the course of Senate debate on the bill, Senator Thurmond read into the record a law review note that stated: "[F]orcing the defendant to pay this premium is unfair to defendants." See 122 Cong. Rec. S16657, S16659 (1977) (reading from Note, Attorneys' Fees in Individual and Class Action Antitrust Litigation, 60 CAL. L. Rev. 1656, 1669-70 (1972)), reprinted in SOURCE Book at 151, 156 (also noting that in antitrust cases that provide for fee shifting, the source of risk compensation should be a portion of the plaintiff's treble damage recovery). But see Stanford Daily, 64 F.R.D. at 686 (asserting that contingent fee doctrine "does not concern the source of payment for legal services"). 
While conceding the problems with making defendants subsidize cases against other potentially innocent defendants, one commentator argues that contingency multipliers are fair in a broader sense because "those whose violation of the law makes enforcement necessary pay the costs of a system that makes meritorious suits possible." ${ }^{127}$ This rationalization is unpersuasive, however, because it discounts the inequities to defendants and fails to consider that current incentives may be sufficient to encourage lawyers to bring meritorious civil rights suits.

Third, in important respects civil rights plaintiff's lawyers bear less risk of noncompensation under contingency arrangements than do their counterparts in tort and common fund cases. ${ }^{128} \mathrm{Un}$ like the contingent fee tort lawyer, who is paid in direct relation to a graduated measure of the extent of his success (the size of the damage award), civil rights lawyers are awarded attorney's fees under the lodestar approach, which has no such grading. Thus, civil rights plaintiff's attorneys face no risk of nonpayment from unreasonably low damage awards, and they may in fact receive fee awards far in excess of any damages their clients receive. ${ }^{129}$

In addition, a civil rights attorney has an incentive to take a case regardless of whether the plaintiff is indigent or not, since if she prevails the fees come out of the defendant's pocket. If the attorney wins, she is almost assured of receiving a fee: Congress has expressed a desire for limited court discretion to deny fees ${ }^{130}$

127 Leubsdorf, supra note 15, 90 YALE L. J. at 502.

123 However, it should be recognized that in some ways, civil rights actions under section 1983 and related statutes are riskier for plaintiffs than are other forms of litigation. For example, negligence is not actionable under section 1983, and some defendants will be protected by sovereign immunity. See Kirchoff, 786 F.2d at 323-324.

129 For example, in its latest decision under section 1988, the Supreme Court upheld a fee award seven times the size of the damages awarded. City of Riverside v. Rivera, $106 \mathrm{~S}$. Ct 2686 (1986) (applying lodestar approach even in civil rights damages actions). See also Skoda v. Fontani, 646 F.2d 1193 (7th Cir. 1981) (per curiam) (reversing lower court's denial of fees to plaintiff's attorney who won damage award of one dollar); Milwe v. Cavuoto, 653 F.2d 80, 84 (2d Cir. 1981).

${ }^{130}$ Both the House and Senate Reports on the Fees Act bills cite Newman v. Piggie Park Enterprises, Inc., 390 U.S. 400, 402 (1968) to note that a prevailing party "should ordinarily recover an attorney's fee unless special circumstances would render such an award unjust," H. REP. No. 1558 at 6, reprinted in SouRce BooK at 214; S. REP. No. 1011 at 4 , reprinted in Source Book at 10. The "special circumstances" exception to the presumption in favor of awarding fees has been quite narrowly construed. See, e.g., New York Gaslight Club, Inc. v. Carey, 447 U.S. 54, 68 (1980); see also Note, Judicial Discretion and the 1976 Civil Rights Attorney's Fees Awards Act: What Special Circumstances Render an Award Unjust?, 51 Fordham L. Rev. 320, 338-44 (1982) (arguing for broader "totality of the circumstances" test to limit courts' discretion to deny fees under special circumstances); Note, Awards of Attorney's Fees in the Federal Courts, 56 ST. John's L. REv. 277, 324-30 
and, accordingly, courts have been reluctant to deny fees entirely. ${ }^{131}$

Not only is a "prevailing party" almost assured of getting fees, but courts have further reduced nonpayment risk by defining "prevailing party" quite generously. ${ }^{132}$ In some courts, for example, a civil rights lawyer "prevails," and thus receives a reasonable fee, whenever the plaintiff gains some relief. ${ }^{133}$ By defining success broadly, courts reduce the risks associated with losing a standard contingent fee case; thus civil rights attorneys are subject to considerably less risk of noncompensation than are personal injury lawyers, who may "prevail" but win only a percentage of nominal damages. ${ }^{134}$

2. The hidden incentives to bring civil rights cases. Despite its intuitive appeal, the argument that lawyers will not have sufficient incentives to take contingent fee civil rights cases without a multiplier is flawed for several reasons. First, it discounts the non-

(1982) (discussing "Newman-Northcross" presumption in favor of awarding fees and criticizing case-by-case "bright prospects" approach to "special circumstances" adopted in Zarcone v. Perry, 581 F.2d 1039 (2d Cir. 1978)). See generally LaRson, supra note 24, at 44-51 (noting that only one appellate decision to date had ever upheld a "special circumstances" claim, and that most decisions summarily dismiss such claims). But cf. Note, Surveying the Law of Fee Awards Under the Attorney's Fees Awards Act of 1976, 59 Notre Dame L. REv. 1293, 1297-99 \& n.28-32 (1984) (citing several decisions denying fees to prevailing parties and suggesting that such denials frustrate congressional intent).

${ }^{131}$ Rivera v. City of Riverside, 763 F.2d 1580 (9th Cir. 1985), aff'd, 106 S. Ct. 2686 (1986) (fee awarded not excessive merely because it is greater than jury's damage award). The Supreme Court in Hensley v. Eckerhart, 461 U.S. 424, 433-34 (1983), recognized the "prevailing party" standard as a "generous formulation." Numerous cases explicating the standard are collected in LaRson, supra note 24, at 51-62.

${ }^{132}$ See, e.g., Hensley, 461 U.S. at 433; see also LARson, supra note 24, at 51-62 (stating that the prevailing party standard is generally met whenever plaintiffs win "some of the benefit sought"); Note, supra note 130, 59 Notre DAME L. REv. at 1295-99 (surveying courts' treatment of "prevailing party" and "special circumstances"). But see Fioretti \& Convery, supra note 120, 16 J. MAR. L. REv. at 275-78, 285 \& nn.61-64 (sharply criticizing the Skoda case and recommending change to a less generous standard of "clear and substantially prevailing").

1ss The extreme example is Skoda, 646 F.2d at 1193, where the Seventh Circuit ordered reasonable fees for a plaintiff's lawyer who had sought $\$ 200,000$ in damages and obtained one dollar. See also Skoda v. Fontani, 519 F. Supp 309 (N.D. Ill. 1981) (on remand). See also, e.g., Nadeau v. Helgemoe, 581 F.2d 275, 278-79 (1st Cir. 1978) (plaintiffs are prevailing parties "if they succeed on any significant issue in litigation which achieves some of the benefit the parties sought in bringing the suit"), and cases cited therein (awarding fees on recovery of nominal damages).

${ }^{234}$ On the other hand, civil rights lawyers argue that they are subject to the risk of having their hours reduced by a judge. To the extent this is true, the courts should attempt to remedy any ad hoc unfairness through a more standardized approach to lodestar calculation, rather than by treating the risk of judicial unfairness as an external risk of nonpayment for which plaintiff's lawyers must be compensated. 
monetary incentives (so-called psychic benefits) that motivate civil rights litigation-incentives attested to by the existence of legal aid clinics and true pro bono litigation. ${ }^{135}$ Second, it assumes that other elements of reasonable fee determination-hourly rates and hours spent-are correctly measured, when in fact there are strong reasons to suspect that both have an upward bias. ${ }^{136}$

Court-defined market rates provide a variety of hidden incentives. Surely some lawyers take cases where their risk-discounted expected rate is below the "reasonable market hourly rate" because they do not receive this market rate in their normal practice. Since the Supreme Court has said that reasonable hourly rates should be based on the norms in a community, not just on an individual lawyer's past billing rates, ${ }^{137}$ that market rate plainly will be higher than many lawyers could receive in the market for their own services. ${ }^{138}$

In addition, civil rights lawyers benefit from the fact that "reasonable" rates are set not according to the rates for civil rights practice, but rather by the considerably more lucrative standards of complex commercial litigation. The Senate specified that fees awarded under section 1988 should "be governed by the same stan-

13s See, e.g., Armstrong v. Reed, 462 F. Supp. 496, 502 \& n.5 (N.D. Miss. 1978) (noting that staff attorney with civil rights organization was not dependent on his private practice for his livelihood, court finds contingency factor not relevant, implicitly recognizing that incentives of multipliers have no effect on some civil rights lawyers). See also Breger, supra note 27, $47 \mathrm{LAw} \&$ CONTEMP. ProBS. at 259 (noting a lack of ex ante effect in current multiplier determinations and that "[t]he decision to accept a case more likely depends on the attorney's assessment of its merits, his interest in it, and the state of his calendar"). Certainly, it could be argued that corporate firms accepting true pro bono work do not consider the possibility of receiving fees at all in deciding to take a case. See Ashton v. Pierce, 580 F. Supp. 440, 444 (D.D.C. 1984) (suggesting that law firms may take pro bono cases to provide "learning experiences" for junior lawyers "to break the tedium of everyday practice"). Similarly, one could argue that public interest legal aid groups do not decide which cases to take based on the possibility of obtaining fee enhancements because they have law reform agendas and they wish to maintain tax-exempt status. See Rev. Proc. 75-13 § 3.03, 1975-1 Cum. Bull. 662 .

${ }_{136}$ See, e.g., Laffey v. Northwest Airlines, Inc., 746 F.2d 4, 29 \& n.149 (D.C. Cir. 1984) ("The lodestar figure may therefore inherently include an adjustment for the possibility of not prevailing on the merits, . . . despite the diligent efforts of district judges to separate the two.") (citations omitted); Murray v. Weinberger, 741 F.2d 1423, 1431 (D.C. Cir. 1984) (noting that market-based hourly rate of lodestar "includes an increment for the normal risk of not being paid for some of the hours an attorney expends").

${ }^{237}$ Blum v. Stenson, 465 U.S. 886, 895 \& n.11 (1984) (confirming that reasonable fees are to be "calculated according to prevailing market rates in the relevant community").

${ }^{138}$ Copeland v. Marshall, 641 F.2d 880, 899-900 (D.C. Cir. 1980) (en banc) (awarding prevailing market rate even if resulting in fee larger than lawyer's normal rate); Breger, supra note 27, 47 LAw \& Contemp. Probs. at 260. See also Derfner \& Wolf, supra note 88, at I 18.03[2] (discussing filings necessary to support fee awards and noting that both community market rates and individual billing rates are important in fee requests). 
dards which prevail in other types of equally complex Federal litigation, such as antitrust cases." 139 Public interest lawyers thus will have considerable incentive to undertake cases if the rate is set at the average market rate for commercial litigation. ${ }^{140}$ Even those lawyers who bill at rates in excess of the average commercial market rate should not be discouraged from taking civil rights cases without a contingency multiplier, since they can present affidavits and their own past billing records to justify a higher-than-market hourly rate. ${ }^{141}$

There is no reason to assume that the rate prevailing in the commercial market would not attract lawyers to contingent fee civil rights cases. ${ }^{142}$ Thus, there is no reason to assume that courts' definitions of reasonable fees would be inadequate to attract competent counsel to take meritorious civil rights cases.

Not only may there be hidden risk compensation in judicial definitions of reasonable hourly rates, there also may be extra compensation in the "hours charged" factor of the lodestar. One would expect the hours charged to be biased upwards, since lawyers have incentives to inflate the number of hours claimed (bounded only by the code of professional responsibility) and since plaintiffs have very weak incentives to monitor their attorneys. ${ }^{143}$ Court supervi-

139 S. REP. No. 1011 at 6 , reprinted in SouRce Book at 12 . However, many courts have overlooked this and have not considered higher rates of commercial litigation in civil rights fee cases. See, for example, the cases cited in Larson, supra note 24, at 202-04. See also May v. Cooperman, 582 F. Supp. 1458, 1463 (D.N.J. 1984) (Blum "effects a fundamental change in the law governing the award of attorneys' fees in $\S 1983$ cases. No longer are the fee award principles which evolved in securities and antitrust class actions to be applied unmodified in § 1983 cases.").

${ }_{140}$ See, e.g., Copeland, 641 F.2d at 920-21 (Wilkey, J., dissenting), where, in arguing for cost-plus fee calculation, Judge Wilkey noted that lawyers generally do not "operate on the basis of achieving highest opportunity costs most of the time; by definition, the usual一and entirely satisfactory-reward is less."

${ }^{141}$ See generally Derfner \& WoLf, supra note 88, at I 18.03[2] \& nn. 23-24 (citing cases that consider past billing rates, law school record, publications, and Martindale-Hubbell rating in determining reasonable rates); LARSON, supra note 24, at 195-97 \& n.18 (noting that the proscription of minimum fee schedules after Goldfarb $v$. Virginia State Bar, 421 U.S. 773 (1975), has generally led courts to rely on affidavits, but adding that rates of opposing counsel may also be relevant). Along these lines, it has been suggested that fees be awarded that are equal to the opponent's attorney's fees. Leubsdorf, supra note 15, 90 YaLE L. J. at 501 n.117. But cf. Pharr v. Housing Authority of City of Prichard, 704 F.2d 1216, 1218 (11th Cir. 1983) (reversing district court fee award that was based on the notion that "plaintiff's counsel was worth no more than defendants" ").

${ }_{142}$ See In re Agent Orange Products Liability Litigation, 611 F. Supp. 1296, 1312 (S.D. N.Y. 1985) ("No empirical evidence suggests that this approach [eliminating contingency multipliers] will so discourage the legal profession's efforts on behalf of common fund plaintiffs that it should not be entertained.").

${ }^{143}$ See Kirchoff, 786 F.2d at 324 (describing lawyers' incentives to accumulate hours 
sion of the hours charged may limit the effects of this unambiguous incentive to run up or make up hours, but it seems unlikely that judicial monitoring will be as effective as the private market forces that normally provide incentives to the plaintiff and her attorney to limit hours charged.

Arguments that nonpayment risk compensation is essential also assume that private lawyers and firms operate consistently at 100 percent capacity, that at any given time, all lawyers have the option to work on non-contingent matters at full market rates. But in fact, many lawyers probably bill fewer hours than their work capacity $^{\mathbf{1 4 4}}$ and thus may be willing to spend available time on risky cases.

Consider a lawyer who anticipates working at seventy five percent of potential billing capacity. One would expect him to accept any fee awards case where his chances of prevailing are seventyfive percent or greater, since he can bill all hours reasonably expended on that case. If there are lawyers who do not think they will be able to bill as many hours as they would like to, they should have an incentive to take civil rights cases without any nonpayment risk compensation. There is no indication that Congress intended to go so far as to make all lawyers economically indifferent between retaining their current practice mix and taking civil rights suits. Congress's goal was simply to encourage a sufficient number of competent lawyers to represent the poor. And there is no reason to believe that a lawyer who anticipates billing less than 100 percent of his available hours is necessarily any less competent to represent a civil rights plaintiff than a lawyer whose calendar is full.

It is true that the above argument carried to its extreme might frustrate the goal of ensuring competent civil rights counsel. "Market rates" could be defined so as to encourage only the least qualified, lowest paid lawyers to represent civil rights plaintiffs. Thus, some courts have justifiably read competence to require more than a minimum degree of skill-particularly because of the high priority Congress placed on national civil rights policies. ${ }^{145}$ There is no

and plaintiffs' lack of incentives to monitor).

14" For the argument that there is a "mounting oversupply of lawyers," see D. Bok, $A$ Flawed System of Law Practice and Training, 33 J. LEg. Educ. 570, 579 (1983).

115 See Yates v. Mobile County Personnel Bd., 719 F.2d 1530, 1534 (11th Cir. 1983): without a multiplier to encourage "highly skilled" lawyers to take contingent fee civil rights cases, the court said, "[ $t]$ he enforcement of our civil rights acts would then be entrusted largely to less capable and less successful lawyers who lack sufficient employment. Such an arrangement would ill serve policies of enormous national importance." But see Copeland v. Marshall, 594 F.2d 244, 257 n.75 (D.C. Cir. 1978) (panel opinion). The Copeland panel, in 
evidence, however, that the prevailing market rate in the relevant community is inadequate to attract attorneys with this degree of skill. ${ }^{146}$

\section{In Support of a Cautious Approach}

This comment has shown that the current case-by-case approach to nonpayment risk multipliers is theoretically unsound, wasteful of judicial resources, and ineffective as an incentive. ${ }^{147}$ The Supreme Court thus far has taken a cautious approach, questioning the use of nonpayment risk multipliers in Blum before deciding in Delaware Valley Citizens' Council whether to eliminate these case-by-case multipliers. ${ }^{148}$ Once the case-specific multiplier is rejected, the Court should likewise be cautious before it adopts any across-the-board nonpayment risk multiplier. It should be shown that Congress intended to provide incentives beyond those inherent in unenhanced fees before courts exercise the quasi-legislative, quasi-executive power of multiplying fees for nonpayment risk, especially since the effectiveness of nonpayment risk multipliers in general is open to serious question.

paring down a fee request, acknowledged that establishing a sub-class of lower fees for section 1988 would be contrary to congressional purpose, but at the same time it refused to uphold a fee award calibrated according to the highest fees charged in the private sector. The panel criticized such high rates as "out of line with the ethic of public service with which attorneys are encouraged to engage in public interest litigation" and warned they "may even risk turning the public against the very provisions for the award of attorneys" fees on which appellees rely in this case." Id. The panel decision, however, was overturned by the en banc court. Copeland v. Marshall, 641 F.2d 880 (D.C. Cir. 1980).

116 Admittedly, current determination of reasonable market rates is in a state of confusion. But the problems of a multiplier are independent of problems in reasonable fee determinations. A strong case may be made for establishing a schedule of prevailing market rates in each district. Cf. EQuiTy ACT Hearings II at 301-302 (statement of James E. Ferguson, II). In addition to saving judicial resources, such a uniform rate schedule would enhance the incentive value of fee shifting by creating a certainty heretofore unknown. But courts have adopted a wide range of techniques in defining the prevailing market rate. The Supreme Court may provide further guidance, or Congress may pass pending legislation that sets a cap of $\$ 75$ per hour for attorney rates. See supra notes 5 and 7 and accompanying text.

${ }^{147}$ See Leubsdorf, supra note 15,90 YALE L. J. at 499, arguing that the current approach "seems to rest on the virtually indefensible judgment that every suit not inescapably marked for failure should be brought, regardless of its cost." Professor Leubsdorf goes on to propose that different types of suits should require different multipliers based on policies concerning which suits should be more encouraged. But, he adds, "as it stands, the contingency bonus is not much better, as a flexible policy instrument, than a flat award of attorney fees with no eye to desirability of suit or likelihood of success." Id.

${ }^{148}$ See Pennsylvania v. Delaware Valley Citizens' Council, 106 S. Ct. 3088, 3099-3100 (1986). In Delaware Valley, the Court held that a fee award under the Clean Air Act could not be adjusted upward for "quality of representation," but ordered reargument on whether risk of loss would justify such an upward adjustment. Id. 
Current knowledge about the incentive effects of reasonable fees and nonpayment risk multipliers is simply inadequate to draw conclusions as to whether more or less private civil rights enforcement is desirable. The facile conclusion that eliminating nonpayment risk multipliers would lead to a lower level of civil rights enforcement assumes that the current nonpayment risk multiplier practice provides real incentives to the civil rights bar. Whatever incentives the current system could provide in theory have been weakened considerably by uncertainty and inconsistency both between and within circuits. ${ }^{148}$

If the incentives truly were significant, one would expect to see a for-profit civil rights bar growing to displace civil rights plaintiffs' dependence on legal aid and moonlighting pro bono lawyers. ${ }^{100}$ After nearly ten years, there should be at least some evidence that the possibility of obtaining a nonpayment risk multiplier has some effect on attorneys' decisions to take civil rights cases. In the absence of such a showing, the courts should give careful attention to the policy arguments favoring the elimination of nonpayment risk multipliers.

The simple rule of no contingency multipliers is even more attractive when one considers current government budgetary constraints. ${ }^{151}$ In passing the Fees Act to promote private enforcement of the civil rights laws, Congress intended to avoid placing a heavy burden on public expenditures. Yet the cost to the government of paying for and defending against nonpayment risk multipliers may be doing just that. ${ }^{152}$ Courts should reduce this burden by elimi-

${ }^{140}$ Cf. the analogous reasoning in Evans v. Jeff D., 106 S. Ct. 1531, 1545 n.34 (1986) (conceding possibility that allowing plaintiffs to waive fee claims may reduce incentives to lawyers, but dismissing argument because there is no "reason or documentation to support such a concern at the present time").

${ }_{130}$ Contra Evans, 106 S. Ct. at 1551-52 \& n.7 (1986) (Brennan, J., dissenting); J. Kraus, Ethical and Legal Concerns in Compelling the Waiver of Attorney's Fees by Civil Rights Litigants in Exchange for Favorable Settlement of Cases Under the Civil Rights Attorney's Fees Awards Act of 1976, 29 ViLL. L. REv. 597, 634 (1984) (reviewing studies, estimating, for example, that 0.15 percent of all lawyers in America engaged in public interest practice).

${ }^{151}$ See Equity Act Hearings II at 45, 49 (statement of D. Lowell Jensen, Deputy Attorney General, Oct. 8, 1985, at 10) (claiming that the use of multipliers has increased the amount governments are forced to pay in attorneys' fees by forty-three percent at the federal level and forty-one percent at the state and local levels). Ironically, though the multiplier may be eliminated against governments first, it would appear more fair to tax the government in order to encourage civil rights lawyers than to tax individual defendants, as the government can pass these costs to society. See supra note 124 and accompanying text.

${ }^{132}$ See, e.g., Ashton v. Pierce, 580 F. Supp. 440, 444-45 (D.D.C. 1984):

[Under current practice] [t] he concept of merely making lawyers whole has long since gone out the window. . . . Lawyers who treat [fee shifting provisions] as designed to compensate counsel in the same generous manner as some lawyers are compensated in 
nating the use of such multipliers. ${ }^{153}$

\section{CONCLUSION}

Congress did not specify whether compensation for the risk of nonpayment is appropriate under the Fees Act. Rather, in passing the Act to provide reasonable fees to help private attorneys general enforce civil rights, Congress left the definition of these fees to the courts. The judicial response to the question of nonpayment risk multipliers has been inadequate because it has lacked uniform principles. Case-by-case inconsistencies have diluted the incentives a nonpayment risk multiplier theoretically should create. Confusion over the propriety of multipliers has been compounded by inconsistencies in judicial reasonable fee determinations. Not only have the increasing volume and complexity of fee requests taken up scarce judicial resources, but they have also perpetuated consideration of case-specific factors that distort incentives and create conflicts between attorneys and their clients.

Abandoning case-by-case contingency enhancements in favor of a rule against nonpayment risk multipliers will have little or no demonstrable effect on private enforcement of civil rights, given the weak incentives that survive in the current approach. This argument in no way suggests that other rationales for enhancing the lodestar are not legitimate or indeed vital. It merely urges elimination of nonpayment risk multipliers as a modest step toward a more coherent system of incentives to the civil rights bar.

To this end, courts also should create uniform reasonable rates on which lawyers can rely. Once data are generated under such

private practice should take heed of the consequences. In passing this statute Congress clearly indicated that it did not intend to place such a heavy burden on the public purse. Failure to reach prompt and reasonable fee dispositions by settlement or efficient use of court proceedings may eventually jeopardize the golden goose. Congress, for its part, would do well to consider how the fee-setting process may be streamlined, perhaps through use of arbitration or promulgation of more definitive and simplified standards for passing on such fee requests.

${ }^{153}$ See, e.g., Thomas E. Whlging and Nancy Weeks, Federal Judicial Center, Attorney Fee Petitions: Suggestions for Administration and Management 56 (1985) (suggesting that "[o]ne quick solution to the contingency question is merely to assume that risks of lack of success, nonpayment, and delay are unavoidable features of the legal profession, and that the risk factor is encompassed by the . . . legal fees received"). This rationale, of course, ignores the difference between contingent fee practice and working on retainer, basically equating the risk of losing with the risk of nonpayment. In Laffey $v$. Northwest Airlines, Inc., 746 F.2d 4, 29 (D.C. Cir. 1984), the court of appeals adopted a similarly flawed oversimplification when it noted that the plaintiff's chance of success was 50 percent and therefore not worthy of risk enhancement because the risk was not "exceptional" under Blum. 
uniform incentives, the need for nonpayment risk multipliers can be assessed properly. In the meantime, courts should continue to streamline and simplify fee awards litigation. Abandoning contingency multipliers and their attendant nonpayment risk assessments is a necessary step in this process.

James D. Kole 